\title{
IBADAH SEBAGAI GAYA HIDUP MENURUT ROMA 12:1 \\ DAN IMPLIKASINYA BAGI IBADAH MASA KINI
}

\author{
JAMMES JUNAEDY TAKALIUANG
}

\section{PENDAHULUAN}

Keunikan manusia sebagai ciptaan Allah dibandingkan dengan ciptaan yang lain, oleh karena manusia diciptakan menurut gambar rupa Allah dan puncak dari segala ciptaan. Oleh karenanya sebagai ciptaan yang unik maka manusia menyatakan Allah secara lebih menakjubkan dibandingkan dengan ciptaan lain. Tetapi hal ini tidak menunjukkan bahwa manusia memiliki kedudukan yang sama dengan Allah, manusia adalah ciptaan dan Allah adalah pencipta. Dalam tanggungjawab untuk menyatakan Allah maka manusia harus mengalami perjumpaan dengan Allah. Perjumpaan ini bukan usaha manusia belaka tetapi inisiatif Allah semata dalam memperkenalkan diri-Nya, bertemu serta menyelamatkan manusia. Inilah hakekat hidup manusia yaitu mengenal dan berjumpa dengan Allah karena tanpa hal ini manusia tidak akan pernah mengenal dirinya sendiri. John Calvin dalam Institutes of Religion menulis: "man never achieves a clear knowledge of himself unless he has first looked upon God's face, and descends from contemplating him to scrutinize himself." Sehubungan dengan hal ini Pratt menulis demikian: "Calvin dengan baik mengamati bahwa manusia mengerti siapa dirinya hanya didalam terang Allah itu. Allah adalah sang pencipta dan manusia adalah ciptaan-Nya. Tanpa memandang diri manusia melalui terang ini, manusia tidak akan pernah menangkap apa artinya manusia."2 Oleh karena itu pengenalan Allah adalah urat nadi atau hal yang fundamental untuk manusia. Ferguson menulis demikian :

Hal yang paling penting bagi orang percaya selama berada dalam dunia ini ialah bertumbuh dalam pengenalan akan Allah. Pengenalan akan Allah adalah pusat dari keselamatan orang percaya dan dari semua pengalaman kerohanian yang benar. Pengenalan akan Allah adalah pusat bagi semua pengertian yang benar dalam kehidupan

1 John T. McNeill (Ed), Calvin: Institutes of Religion (Philadelphia: The Westminster Press, 1981), 37. $2003), 3$

${ }^{2}$ Richard L. Pratt, Dirancang bagi Kemuliaan (Surabaya: Penerbit Momentum, 
keKristenan. Pengenalan akan Allah penting bagi pertumbuhan orang percaya. Pengenalan akan Allah adalah merupakan hak istimewa. $^{3}$

Dari kajian ini jelas bahwa pengenalan akan Allah yang dimaksud adalah di dalam Yesus Kristus karena iman Kristen memiliki keunikan dalam hal ini. Iman Kristen memiliki perbedaan yang mendasar dengan iman dalam agama-agama lain dalam hal isinya atau content. Iman Kristen menjadi kesatuan integral dengan struktur jiwa manusia dan menghasilkan nilai-nilai kekekalan dalam hidup manusia. ${ }^{4}$ Iman yang sejati memberikan kepastian dalam segala hal yang terjadi sekarang dan dalam segala hal yang akan terjadi nanti (Eskatologis). Maka keKristenan bukan hanya sebuah sistem agamawi tetapi sebuah relasi. Allah dalam iman Kristen adalah Allah yang berpribadi dan Dia menghendaki supaya diri-Nya dikenal oleh manusia serta umatnya mencari, mendekat dan bersekutu dengan Dia melalui ibadah (bnd. Kel 7:16, 8:1-9; Luk 11:10; Kis 17:27). Sproul menulis dua sebab utama mengapa kita beribadah kepada Allah yaitu: "pertama, Allah menyuruh kita beribadah sebagai suatu kewajiban yang diberikan oleh pencipta kepada ciptaan-Nya. Kedua, pada hakekatnya Allah memang patut menerima ibadah kita." "Ini berarti bahwa ibadah adalah suatu tindakan memuliakan Allah. Searah dengan hal ini Grudem dalam Systematic Theology mendefinisikan ibadah sebagai berikut:

Worship is the activity of glorifying God in His presence with our voices and heart. In this definition we note that worship is an act of glorifying God. Yet all aspect of our lives are supposed to glorify God, so this definition spesifies that worship is something we do especially when we come into God's presence, when we are conscious on adoration of him in our hearts and when we praise him with our voices and speak about Him so others may hear." "7

Carson mengutip apa yang didefinisikan oleh A.P. Gibbs tentang ibadah yaitu: "ibadah adalah dikuasainya hati oleh Allah, bukan berbagai kebutuhannya atau oleh berkat-berkatnya. ${ }^{8}$ Maka ibadah adalah suatu sikap

${ }^{3}$ Sinclair B. Ferguson, Hati yang Dipersembahkan Kepada Allah (Surabaya: Penerbit Momentum, 2002 ), 1-3

${ }^{4}$ Ibid., 5

${ }^{6}$ R.C. Sproul, Menanggapi Allah dalam Ibadah: Pola Hidup Kristen (Malang: Gandum Mas, 1990), 350 1994), 1003

7 Wayne Grudem, Systematic Theology (Grand Rapids, Michigan: Zondervan,

${ }^{8}$ D.A. Carson, Gereja Zaman Perjanjian Baru dan Masa Kini (Malang: Gandum Mas, 1997), 127 
pengagungan dan rasa hormat yang terdalam bagi Allah di dalam Yesus Kristus dan hanya Allah saja yang menjadi fokus utama. Sehingga setiap ibadah selalu menyatakan Allah. Hoon menulis demikian: "Inti ibadah Kristen adalah Allah sedang bertindak untuk memberikan hidup-Nya bagi manusia dan membawa manusia mengambil bagian dalam kehidupan itu." 9 Teolog Lutheran Peter Brunner menjelaskan ibadah dengan menggunakan istilah Jerman Gottesdiest yaitu satu kata yang mencakup baik pelayanan Allah kepada manusia maupun pelayanan manusia kepada Allah. ${ }^{10}$ Nikos A. Nissiotis seorang teolog Ortodoks menyatakan bahwa ibadah pertamatama bukanlah inisiatif manusia melainkan tindakan pendamaian Allah dalam Kristus melalui Roh-Nya. ${ }^{11}$ Selain berbicara tentang tanggapan terhadap karya agung yang telah Allah kerjakan, sedang dikerjakan, ibadah juga memberi dampak kekekalan atau makna eskatologis. Dalam hubungannya dengan hal ini Jean Jaques von Allmen seorang theolog Swiss mendefiniskan ibadah demikian: "Christian worship is an eschatological game." Maksudnya, bahwa keunikan ibadah Kristen adalah pada makna eskatologinya. Seolah-olah apa yang dilakukan umat Kristen dalam ibadah menunjuk pada apa yang akan terjadi kelak dalam kerajan Sorga (Why 4:1 11, 7:9-17). ${ }^{12}$ Ibadah memiliki sifat kekekalan sehingga ibadah adalah tujuan tertinggi. Maka ibadah Kristen adalah sesuatu yang unik yang tidak terdapat dalam ibadah manapun karena semua aspek ada di dalam ibadah Kristen. Bahkan ibadah adalah tujuan dari kehidupan itu sendiri, oleh karena semua yang manusia lakukan adalah ibadah. Ini berarti bahwa kehidupan sama dengan ibadah atau ibadah harus menjadi gaya hidup.

Konsep ibadah sebagai gaya hidup ini harus di implementasikan dalam ibadah Gereja masa kini. Karena pertumbuhan Gereja baik secara kualitas maupun kwantitas ditentukan oleh konsep ibadah. Bahkan praktek ibadah dalam Gereja semua didasarkan pada konsep ibadah. Jika konsep yang di implementasikan adalah keliru maka akan terjadi penyimpangan yang berakibat pada pelaku ibadah yaitu jemaat.

Semua orang yang ada dalam Gereja menghendaki kehadiran Gereja ditengah dunia ini adalah menjadi berkat. Harapan dan cita-cita Gereja ini sangat mulia. Tetapi dalam kenyataan yang ditemui dilapangan beberapa Gereja tidak dapat memenuhi cita-cita dan harapan yang mulia ini. Salah satu faktor penyebab adalah kurang terimplementasinya konsep ibadah yang benar. Beberapa Gereja telah melupakan bahkan menghilangkan

\footnotetext{
${ }^{9}$ James F.White, Pengantar Ibadah Kristen (Jakarta: BPK Gunung Mulia, 2002), 7

${ }^{10} \mathrm{Ibid}$.

${ }^{11}$ Ibid., 10.

${ }^{12}$ Yakub B. Susabda, Mengenal dan Bergaul dengan Allah..., 254
} 
unsur-unsur dasariah ibadah serta penyimpangan tujuan umat yang beribadah. John Stott menulis sebagai berikut:

Bahwa kita yang menyebut diri 'injili' tidak tahu banyak bagaimana harus beribadah. Pengabaran injil atau evangelisasi adalah spesialisasi kita, bukan ibadah. Kita tampaknya hanya punya sedikit rasa tentang kebesaran dan keagungan Allah yang Mahakuasa. Kita tidak bersujud dihadapan-Nya dengan kagum dan gentar. Kecenderungan kita adalah sok jago, kurang ajar dan sombong. Kita tidak ambil pusing dalam mempersiapkan pelayanan ibadah kita. Sebagai akibatnya ibadah kita kadang-kadang berjalan begitu saja, mekanis, asal jadi dan kering. Pada kesempatan lain ibadah kita gegap gempita sampai benar-benar kehilangan kekhidmatannya. Tak heran mereka yang mencari kenyataan sejati sering mengabaikan kita. $^{13}$

Alan Wolfe, seorang sarjana dan peneliti menerbitkan sebuah studi yang tajam dari kehidupan keagamaan bahwa yang tampil menyolok adalah tokoh kaum injili. Ia menuliskan sebagai berikut:

Paham injili sekarang ini memamerkan sebuah keinginan yang sangat kuat untuk meniru konsep bangunan mewah dan musik populer yang membuatnya kehilangan perbedaan-perbedaan religius yang pernah dimilikinya. Kebenarannya ialah terdapat kecenderungan menguat akan adanya perbedaan tipis antara sebuah aktivitas duniawi seperti industri hiburan populer dengan upaya dari banyak mega gereja Injili untuk menarik orang sebanyak mungkin dengan ongkos berapa pun."14

Maka George Barna menyimpulkan bahwa setiap hari Gereja justru lebih seperti dunia yang semestinya diubahkan. ${ }^{15}$ Michael Horton seorang teolog Injili meratap setelah membaca hasil survei dari The Gallup Organization dan The Barna Group bahwa orang-orang Kristen Injili nampaknya sedikit demi sedikit hendak memeluk gaya hidup sebagai kaum hedonis, materialistik, berpusat pada diri sendiri dan berperilaku amoral dalam hal seksual seperti dunia pada umunya. ${ }^{16}$ Inikah wajah Gereja masa kini? masihkah ada ibadah yang sejati dalam Gereja?

Dalam hubungannya dengan perubahan zaman dari modern ke post modern dimana orang-orang postmodern lebih suka hal-hal yang trans

\footnotetext{
${ }^{13}$ John Stott, The Living Church (Jakarta: BPK Gunung Mulia, 2007), 30

14 Ronald J. Sider, The Scandal of the Evangelical Conscience (Surabaya: Literatur Perkantas, 2007), 22

${ }^{15}$ Ibid., 23

${ }^{16}$ Ibid., 22
} 
history atau transenden dan sangat mengabaikan logika, telah memberikan pengaruh dalam praktek ibadah masa kini, dimana ibadahnya lebih bersifat mistis bahkan sinkritis. Tradisi-tradisi penyembahan berhala dimasukkan dalam ibadah Kristen sehingga motivasi beribadah hanya terbatas pada tanda-tanda ajaib. Selain itu juga tanda-tanda ajaib Allah hanya dibatasi melalui media-media tertentu. Maka ibadah dengan Allah hanyalah untuk menikmati berkat-berkat Allah bukan Allah sendiri. Allah hanya menjadi sarana (tools) bukan sasaran. Jika Allah mampu melakukan tanda-tanda ajaib maka Allah hadir dan ada dalam ibadah. Jika tidak ada tanda-tanda ajaib maka Allah tidak ada dalam ibadah (functional God). Salah satu unsur ibadah Kristen adalah pesta rohani dimana dalam pesta rohani tersebut menunjuk kepada pengharapan. Itulah sebabnya Tuhan memerintah melakukan sakramen perjamuan kudus karena hal ini adalah tanda surgawi dari realita rohani di dalam kerajaan surga. Para reformator menyebut sakramen sebagai pledge atau janji Allah. ${ }^{17}$ Susabda mengutip John A Lasco tentang kebenaran dalam hubungan dengan sakramen demikian: "I hope that you all, sitting down at this Supper, have perceived by the eye of your faith that blessed time in the Kingdom of God when you sit at the table with Abraham, Isaac dan Jacob."18 Sakramen diubah fungsikan hanya sebagai sarana utama perjumpaan dengan mujizat Allah bukan Allah sendiri. Akibatnya sakramen di kultuskan sehingga ukuran untuk melihat dan merasakan tanda-tanda ajaib hanya ada dalam sakramen. Tuhan dimasukkan dalam kotak khusus yaitu perjamuan kudus. Ini berarti membatasi Tuhan dalam karya-Nya.

Dalam praktek ibadah yang lain secara khusus pelaksanaan unsur ibadah pujian, seringkali dilakukan dengan jiwa yang kosong dan kasih yang hambar, maka pujian seringkali hanya untuk kemuliaan manusia bukan Allah. Pujian harus menyentuh perasaan dan ketika perasaan tersentuh maka kepuasaan batiniah tercapai dan itulah ibadah. Apakah demikian pujian dalam ibadah? Jika pujian yang dilakukan hanya untuk mengisi kekosongan perasaan dan hasrat tertinggi adalah pencapaian kepuasaan batiniah, maka disinilah muncul subjective truth sehingga kebenaran ini bersifat relativ. Karena pengalaman kepuasaan batiniah bukan dengan landasan objective truth yaitu firman Allah. Pengabaian Firman Allah dalam ibadah Kristen berarti sama dengan sebuah pengkhianatan dalam ibadah, artinya firman hanyalah sampah. ${ }^{19}$ Unsur lain

\footnotetext{
${ }^{17}$ Susabda, Mengenal dan Bergaul..., 260

${ }^{18}$ Ibid.

19 Hans Maris, Gerakan Karismatik dan Gereja Kita (Surabaya: Penerbit Momentum, 2008), 34.
} 
yang menjadi sorotan dalam ibadah adalah masalah charismata. Dalam hal ini charismata dimunculkan dalam ibadah Kristen menjadi suatu kewajiban. Dengan kata lain, tanpa charismata karya Roh kudus belum lengkap. Apakah ukuran seseorang dalam beribadah hanya karena memiliki charismata?

Pertanyaan yang muncul adalah jika semua unsur dalam ibadah sudah terpenuhi dan bahkan dilaksanakan mengapa Gereja masih belum maksimal dalam menjalankan cita-citanya yaitu Gereja yang menjadi berkat? Mengapa masih ada diskriminasi ras dalam Gereja? Mengapa masih terjadi KDRT (Kekerasan Dalam Rumah Tangga) di anggota Gereja? Mengapa masih ada perceraian? Mengapa masih ada ketidak taatan seksual? Mengapa filsafat materialisme, relativisme dan egoisme berhembus kencang dalam Gereja? Serta ada banyak bentuk masalah sosial yang ada yang dalam Gereja.

Semua fakta ini tidak dapat disangkali bahwa dalam tubuh Gereja masih ada banyak skandal yang terjadi. Apakah Gereja gagal beribadah? Gereja tidak pernah gagal beribadah hanya Gereja belum menerapkan ibadah secara holistik. Selama ini Gereja membatasi ibadah hanya dalam sistem ceremonial. Ini berarti menutup ruang gerak dari pemahaman ibadah. Karena itu Gereja harus terus maju dan berkembang dalam tugas dan panggilannya. Menyikapi hal ini maka pengajaran tentang ibadah sebagai gaya hidup menurut Rasul Paulus dalam Roma 12:1-2, menjadi pegangan utama dalam Gereja demi terwujudnya ibadah yang sejati dan menghadapi semua skandal yang akan mengancam Gereja.

\section{ANALISIS EKSEGETIS ROMA 12:1}

Untuk mendapatkan pengertian yang jelas tentang teologi ibadah menurut Rasul Paulus dalam Roma 12:1-2, maka dalam bab ini Penulis akan memaparkan dua pokok pembahasan: (1) Analisis konteks kitab, (2) analisis eksegetis Roma 12:1.

\section{Analisa Konteks Kitab}

Dalam bagian ini penulis akan menguraikan pikiran-pikiran Paulus dalam surat Roma, menyangkut seluruh konteks dalam kitab ini yang disebut konteks dekat dan juga dari luar kitab yang disebut konteks jauh. 


\section{Konteks Dekat}

Rasul Paulus bukanlah pendiri jemaat Roma. Tetapi dia mempunyai keinginan untuk mengunjungi jemaat Roma. Sebagaimana beberapa surat yang ditulis, Rasul Paulus memulai dengan pendahuluan atau salam, dimana dia menjelaskan posisinya sebagai seorang Rasul Kristus (1:1-15), kemudian dia menguraikan tentang kabar baik yaitu Injil Allah yang merupakan tema utama dalam kitab ini (1:16-18), menyusul pada bagian berikut yaitu pasal 1:18-3:20, uraian tentang keberadaan manusia baik Yahudi maupun non-Yahudi sama-sama berada di bawah murka Allah.

Semua manusia telah berada di bawah murka Allah dan tidak ada jalan lain selain dibenarkan oleh Allah, inilah anugerah terbesar bagi hidup manusia dari yang hina menjadi mulia dan dari tidak percaya menjadi dipercaya. Selanjutnya memasuki pasal 3:21-31, merupakan wujud pembenaran oleh iman semua yang terjadi adalah anugerah Allah. Tetapi ada semacam peralihan pada pasal 4 yaitu tentang Abraham. Van den End menggunakan istilah Midrasy tentang Abraham yang membuktikan isi pasal 3:21-31. ${ }^{20}$ Pasal 5-8 adalah merupakan perwujudan pembenaran ilahi yaitu kehidupan baru berdasarkan pembenaran oleh iman. Berkaitan dengan hal ini, Van den End mengatakan sebagai berikut:

Dibenarkan oleh iman berarti bahwa orang percaya telah masuk kedalam lingkungan kasih karunia (ps. 5), menempuh kehidupan baru bersama Kristus (ps. 6), dibebaskan dari kurungan hukum taurat (ps. 7), dengan ekskurs mengenai peranan hukum taurat dalam hubungan dengan dosa dalam diri manusia) dan menjadi tempat pendiaman Roh yang olehNya mereka mampu memenuhi tuntutan hukum taurat (8). ${ }^{21}$

Perbedaan yang mencolok ialah antara pasal 7 dan 8 . Pasal 7 berbicara penuh soal hukum taurat sedangkan pasal 8 berbicara soal Roh Kudus. Fakta lain yang di ungkapkan oleh Paulus bahwa kita adalah anakanak Allah (sebagai meterai Roh Kudus) maka kita juga adalah ahli warisnya dan penderitaan yang kita alami adalah jalan menuju kemuliaan.

Selanjutnya pasal 9-11 merupakan hubungan antara pembenaran dengan bangsa Yahudi, pilihan atas Israel dan kegagalan Israel. ${ }^{22}$ Selain itu juga pasal 9-11 adalah jawaban terhadap tuduhan yang diajukan kepada

${ }^{20}$ Th. Van den End, Tafsiran Alkitab: Surat Roma (Jakarta: BPK Gunung Mulia, 1995), 11

${ }^{21}$ Ibid.

${ }^{22}$ Merril C. Tenney, Survey Perjanjian Baru (Malang: Gandum Mas, 1992), 337 
Paulus yaitu pemberitaan tentang Allah, dimana Paulus katakan bahwa Allah telah menolak umat-Nya dan bahwa karena itu Allah yang diberitakan Paulus adalah Allah yang tidak dapat diandalkan. Penjelasan lain dari pasal ini yaitu Paulus meletakkan asas Gereja serta kehidupannya. Akan tetapi kehidupan itu bukan hanya asas saja atau sebuah teori tetapi bisa dipraktekkan dalam hidup tiap hari, dan penjelasan tentang hal ini pada pasal 12:1-15:13 yaitu nasehat yang bersifat umum dan menyangkut problem konkrit di dalam jemaat Roma. Keseluruhan nasehat praktis pada pasal 12-15 berbicara tentang bagaimana sikap orang Kristen dalam berhubungan. Hubungan yang paling awal dilakukan adalah hubungan dengan Allah yaitu pasal 12:1-2, kemudian sesudah itu ayat 3-8 menjelaskan hubungan orang Kristen dengan dirinya sendiri secara khusus menyadari setiap karunia yang diberikan oleh Allah untuk kemuliaan Allah, bukan hanya untuk kepentingan diri sendiri. Artinya tiap-tiap anggota jemaat mempunyai tugas yang harus dilakukan untuk tubuh Kristus. Karunia yang diberikan oleh Tuhan itu untuk saling melengkapi bukan untuk saling menonjolkan diri diantara sesama anggota jemaat. Setelah menyadari hubungan dengan diri sendiri Paulus menekankan lagi hubungan dengan orang lain secara khusus tentang kasih dalam keluarga Allah (ay. 913). Pada bagian berikut tentang sikap terhadap musuh atau hubungan kita dengan musuh kita. Sikap orang percaya bukan membalas tetapi melayani jika hal ini dilakukan, maka seperti menumpukan bara api di atas kepala mereka (ay. 20). Setelah memberikan nasehat tentang bagaimana hubungan dengan Allah, diri sendiri, sesama dan bahkan musuh kita, Paulus melihat bukan hal-hal yang hanya dalam lingkup sendiri saja tetapi bergerak maju dengan melihat bagaimana hubungan kita dengan pemerintah seperti yang nampak pada pasal 13:1-7. Hal ini perlu dilakukan oleh karena pemerintah adalah wakil Allah di dunia. Ada tiga hal utama untuk menjelaskan pengertian Paulus tentang pemerintahan sebagai wakil Allah di dunia yaitu:

Sebab tidak ada pemerintahan yang tidak berasal dari Allah (ay 1b). Pemerintahan ditetapkan oleh Allah (ay 1c).

Konsekwensinya, barang siapa yang melawan pemerintah, melawan Allah (ay. 2a).

Tekanan pemikiran Paulus yaitu pemerintahan sebagai wakil Allah ini menjelaskan kepada orang Kristen tentang ketaatan yaitu bukan rasa takut karena dorongan batin yang dalam, artinya kita harus memiliki sikap yang benar terhadap pemerintahan yaitu membantu mereka dalam melaksanakan tugas bahkan memberikan pengertian bahwa mereka sedang mengerjakan pekerjaan Allah. 
Setelah menjelaskan sikap taat kepada pemerintah (ay. 1-7) dan perwujudan nilai kristiani (ay. 8-10). Paulus menutup pasal ini dengan menyajikan alasan yang telah diberikannya tentang dekatnya keselamatan yaitu kedatangan Kristus kembali (ay. 11-14). Sehingga kita harus menghindari semua gaya hidup yang tidak sopan artinya gaya hidup serta nilai-nilai yang diberikan oleh dunia ini. Dalam pasal ini dijelaskan yaitu: pesta pora, kemabukan, percabulan, hawa nafsu, perselisihan dan iri hati. Orang Kristen harus memiliki nilai Kristen yaitu kasih yang terus-menerus, karena kasih akan membawa orang percaya untuk menanti kedatangan-Nya.

Rasul Paulus melanjutkan nasehatnya (ps. 14:1-15:13) dengan melihat masalah yang terjadi dalam jemaat yaitu adanya golongan orang kuat dan lemah, yang membawa kepada kebiasaan saling menghakimi, sehingga hal ini menjadi batu sandungan di antara sesama anggota jemaat (14:13). Tapi Paulus menekankan kesatuan di antara kedua golongan yang telah tercipta ini. Akhirnya pasal 15:14-16:27, merupakan bagian penutup yang berisi ucapan selamat untuk berbagai orang dan rumusan doxologi. ${ }^{23}$

\section{Konteks Jauh}

Dalam memahami konsep tentang ibadah yang sejati, maka tidak lepas juga dengan kitab-kitab di luar Roma atau disebut konteks jauh atau dapat dikatakan bahwa topik tentang ibadah ini dibahas juga dalam bagian surat-surat Rasul Paulus lainnya seperti Galatia dan Korintus. Akan tetapi dari segi isi surat Roma memiliki perbedaan oleh karena banyak ahli mengatakan bahwa kitab ini berisi tentang dogma yang sangat jelas sekali. Ini tidak berarti bahwa surat-surat tulisan yang lain tidak bermakna. Tetapi perbedaan yang nampak hanyalah dari sisi sistematika penulisan, penjelasan mengenai isi memiliki kesamaan, misalnya konsep tentang Roh dan Daging dalam Roma 8, dengan Galatia 5:16-26, selain itu juga konsep dibenarkan karena iman dalam Roma 3:21-31 memiliki kesejajaran dengan memiliki kesejajaran dengan Galatia 3:1-14. Mengenai ibadah yang diungkapkan dalam Roma 12:1-2, sebenarnya juga memiliki kemiripan dalam surat Korintus 3:16-17 yaitu tentang tubuh adalah Bait Allah yang perlu dijaga kekudusannya. Dalam Roma 12:1-2 diungkapkan bahwa tubuh ini adalah persembahan bagi Allah dan yang kudus. Artinya kekudusan hidup berlaku terus bagi hidup tiap-tiap hari, karena hidup ini adalah bait Allah, dimana dalam bait Allah ibadah tercipta senantiasa. Wujud dari ibadah yang sejati dalam Roma 12:1-2 adalah hidup sebagai orang

\footnotetext{
${ }^{23}$ Van den End, Tafsiran Alkitab: Surat..., 11-12
} 
merdeka, yaitu lepas dari kutuk dosa yang mengikat, memiliki gaya hidup yang berbeda "janganlah kamu menjadi serupa dengan dunia ini," serta melayani sesama dalam kasih. Wujud dari pembenaran Allah adalah munculnya kasih dan jiwa melayani hal ini diungkapkan juga oleh Paulus dalam Galatia 15:13, memiliki kemerdekaan bukan untuk melakukan dosa tetapi melakukan melayani sesama dengan dalam kasih.

Dari pemikiran Paulus tentang ibadah dalam semua surat-surat tulisannya, intinya adalah ibadah merupakan tanda dari orang yang telah dibenarkan oleh Allah. Pembenaran Allah itu meliputi seluruh aspek hidup manusia (totalitas hidup) dan totalitas hidup inilah yang dipersembahkan kepada Allah sebagai ibadah, dan persembahan tubuh ini adalah kudus.

\section{Analisa Eksegetis Teks}

Pada bagian ini penulis mempresentasikan pokok-pokok mengenai: nasehat atas dasar kemurahan Allah, mempersembahkan tubuh sebagai persembahan yang hidup, kudus dan berkenan, serta ibadah yang sejati.

\section{Nasehat atas dasar kemurahan Allah (ay. 1)}

Sebelum melihat istilah-istilah yang ada dalam bagian ini (ay. 1) maka penulis melihat juga satu istilah penting yaitu kata karena itu di mana kata ini menunjuk kepada suatu kesatuan yang tidak terpisahkan dengan pasal sebelumnya yaitu pasal 1-11. Jadi ada kontinutias yaitu dengan penggunaan kata ou-n yang berfungsi sebagai kata penghubung. Rasul Paulus kembali memberikan nasehat-nasehat praktis, dia tidak hanya berbicara tentang teori saja yaitu pembahasan tentang doktrin-doktrin Kristen yang sudah dia katakan pada pasal sebelumnya (1-11). Pada bagian ini Paulus menjelaskan lebih rinci untuk menunjukan bahwa Yesus Kristus adalah Tuhan untuk seluruh bagian kehidupan ini. Cranfield memberikan penjelasan tentang kata ou-n serta implikasinya demikian:

Oun is here better understood not as a mere transition-particle, but as having its full force and indicating that what is going to be said follows from what has already been said. The implication of this "therefore" is that Christian ethics are theologically motivated or to put it in a different way that christian obedience is his response to 
what God has done for him in Christ, the expression of his gratitude. $^{24}$

Hegelberg menerjemahkan kata ou-n dengan karena itu dan mengatakan bahwa pemakaian kata ini menyatakan bahwa dorongan ini mempunyai dasar dalam kemurahan Allah seperti yang diuraikan dalam pasal 11:23-32, yang merupakan puncak dari seluruh diskusi teologi surat Roma. ${ }^{25}$ Jadi, dalam bagian ini ia telah memasuki bagian yang praktis. Barclay menjelaskan hal ini demikian:

Di sini kita menemukan kembali pola penulisan Paulus yang selalu ia pakai apabila ia menulis surat kepada teman-temannya. Ia selalu mengakhiri surat-suratnya dengan nasehat praktis. Jalan pikirannya memang dapat menyelidiki sampai kepada hal-hal yang tidak terhingga tetapi ia tidak pernah sesat (ngambang); ia selalu mengakhiri surat-suratnya dengan menetapkan dasar dimana ia berpijak. Ia dapat menggumuli masalah-masalah theologia yang terdalam, tetapi ia selalu mengakhirinya dengan tuntutan etis yang praktis, yang berlaku bagi tiap-tiap orang. ${ }^{26}$

Uraian di atas memberikan petunjuk kepada kita tentang bagaimana kita harus hidup. Artinya bagaimana kita berpikir memberi dampak kepada bagaimana kita hidup. Pemahaman kita yang tepat tentang Allah, manusia, dosa, anugerah, dan doktrin-doktrin yang lain akan menyanggupkan kita hidup secara tepat.

Pasal 12 ini dimulai dengan istilah parakale,w (kata kerja, indikatif present aktif, orang pertama tunggal). ${ }^{27}$ Kata parakale, w berasal dari dua kata para dan kale, w. Mengenai dua kata ini storng menguraikan demikian: "para; a primary prep: prop, near; I.e (with gen) from beside (lit or fig), (with dat.) at (or in) the vicinity of (object or subject), (with acc) to the proximity with local (espec, beyond or oppsed to). ${ }^{28} \mathrm{kale}$, w: to call (prop. Aloud but used in variety of applications, dir or other wise): bid call (forth), (whose) name (was called). ${ }^{29}$ Penggabungan

${ }^{24}$ C.E.B. Cranfield, The Epistle to the Romans (Scotland: T\&T, Clark LTD, Edinburgh, 1979), 595

${ }^{25}$ Dave Hagelberg, Tafsiran Roma: Dari Bahasa Yunani (Bandung: Yayasan Kalam Hidup, 1998), 234

${ }^{26}$ Barclay, Pemahaman Alkitab..., 232

${ }^{27}$ Barbara and Friberg (ed.), Analytical Greek..., 499

${ }^{28}$ James Strong, The New Strong's Complete Dictionary of the Bible Words (USA: Thomas Nelson Publishers, 1996), 673-674

${ }^{29}$ Ibid., 639 
kedua kata ini para (para) dan kale, w (kaleo) menjadi parakale, w (parakaleo) diterjemahkan to call near, i.e invite, invoke (by imploration, hortation or consolation): beseech, call for (be of good). Comfort, desire, (give), exhort (tation), intreat, pray." ${ }^{30}$ A linguistic Key memberikan pengertian untuk parakale, w demikian: To admonish, to encourage, to exhort. To word was used in classical Greek of exhorting troops were about to go in battle. Here it a request based on apostoloc authority of Paul. ${ }^{31}$

Sehingga istilah parakale, w diterjemahkan aku menasehatkan adalah suatu kegiatan yang terjadi secara terus menerus atau berulangulang. Tetapi bukan hanya sebuah nasehat yang bersifat anjuran biasa sehingga perlu dipertimbangkan tetapi ada semacam dorongan yang kuat yang penuh kuasa, dimana kuasanya tidak bisa ditolak tetapi harus dilakukan. Hagelberg menjelaskan bahwa istilah ini (menasehatkan) menunjuk pada suatu ketaatan yang berakar dalam Injil Kristus sehingga nasehat yang dimaksudkan mempunyai wibawa yang sangat kuat. ${ }^{32}$ Maka kedua makna dalam kata parakale, w yaitu dorongan yang begitu mendesak serta wibawa. Hal ini lebih mendasar lagi dari nasehat yang Paulus ungkapkan disini adalah dasar utama dari nasehat ini adalah pada kemurahan Allah. Sehingga nasehat yang Paulus berikan ini adalah dasar motivasi dan dorongan yang bersifat Kristiani. Diluar Kristus orang mendorong dengan ancaman terutama ancaman hukuman kekal. Yang lain lagi mendorong para pengikutnya dengan kuasa kebencian, tetapi Allah kita mendorong kita dengan kuasa kasih. ${ }^{33}$

Istilah yang berikut ini ialah kemurahan yang diterjemahkan mercy (NIV \& NKJV), yang dalam bahasa Yunaninya oivktirmw/n dalam bentuk kata benda, genitiv, maskulin, jamak. ${ }^{34}$ Kata mercy disini menunjuk kepada Allah tw/ qew/I artinya mercy adalah milik Allah. Maka KJV tepat menerjemahkan God's mercy. Istilah lain untuk kata mercy adalah eleos. Dalam $L X X$ secara normal kata ini digunakan dari bahasa Ibrani "hased." Leon Morris dalam Paul Dictionary menjelaskan istilah ini demikian: "Hased is chieftly used of God's relationship with his people in which the notion of grace rather than obligation is prominent. God's hased issues in his covenant with Israel and by it He request to abandon Israel

\footnotetext{
${ }^{30}$ Ibid., 674

${ }^{31}$ Reinecker \& Roger, Jr (Ed), A Linguistic Key..., 375

${ }^{32}$ Hagelberg, Tafsiran Roma..., 235

${ }^{33}$ Ibid.

${ }^{34}$ Barbara and Friberg (Ed), Analytical Greek..., 499
} 
when the nation is faithless." 35 Dalam bagian ini Paulus menggunakan istilah oivktirmw/n pada kata mercy. Istilah oivktirmw/n, berasal dari bahasa Ibrani Rahamim yang diambil LXX, dimana kata ini digunakan sebanyak 6 kali. Kata ini diartikan oleh Leon Morris dalam Paul Dictionary demikian: "A terms which seems to denote the feeling kinship between those born from the same womb or the maternal feeling of a mother who has given birth (rehem, womb). ${ }^{36}$ Berkenaan hal ini Cranfield menjelaskan demikian:

The use of the plural oivktirmw/n would suggest a number of different manifestations of compassion; but here (as in 2 Cor 1:3; Phil 2:1) it probably reflects the influence of the LXX, which regularly respresent Hebrew plural RAHAMIM by plural of oivktirmwos. The Vulgate represent Paul's meaning accurately by singular misericordiam. What he is appealing to as the basis of efhortation is the compassion of God revealed in God's dealing with men through Jesus Christ." 37

Kemurahan selalu berbicara tentang relasi yaitu adanya pertalian yang akrab antara dua pribadi yaitu antara Allah dan manusia. Hal ini dipahami oleh Paulus sehingga dia mendasari nasehat pada kemurahan Allah yang semua ini tercipta oleh suatu relasi yang akrab dengan Allah.

Oleh karena itu istilah mercy pada bagian ini jelas menunjuk kepada apa yang Paulus jelaskan pada pasal sebelumnya secara khusus pasal 9-11, di mana Paulus menjelaskan bahwa keselamatan tidak bergantung kepada perbuatan baik manusia tetapi anugerah Allah (9:16). Maka hal ini berarti bahwa anugerah Allah adalah karya agung Allah yang menyelamatkan manusia berdosa. Disinilah nampak kemurahan Allah bagi manusia. Thomas Van den End menuliskan: "Kemurahan Allah itu bukan hanya hiburan. Tetapi dengan menyelamatkan orang berdosa, Tuhan meneguhkan kembali hak-hak-Nya atas ciptaan-Nya itu."38 Tanpa anugerah Allah dalam hidup manusia, maka tidak ada seorangpun yang bisa datang kepada Allah.

Dalam hubungannya dengan nasehat yang didasari oleh anugerah Allah ini, Cranfield mengutip apa yang ditulis oleh Calvin demikian: "Calvin comment is apt. Paul here "teaches us," he says, that men will never worship God with a sincere heart, or be roused to fear and obey Him with sufficient zeal, until they properly understand how much they are

\footnotetext{
${ }^{35}$ Morris, "Mercy,” Paul Dictionary and His Letter..., 601

${ }^{36}$ Ibid.

${ }^{37}$ Cranfield, The Epistle..., 596

${ }^{38}$ Van den End, Tafsiran Alkitab: Surat..., 563
} 
indebted to His mercy."39 Maka Rasul Paulus ingin mengingatkan kepada seluruh orang percaya agar supaya mereka terus mengingat anugerah Allah yaitu karya agung penyelamatan Allah bagi manusia berdosa dan tidak bermain-main dengan anugerah Allah tetapi sebaliknya semakin serius dengan Allah. Dan juga Rasul Paulus mengingatkan orang percaya bahwa perbuatan baik bukanlah jaminan untuk keselamatan kekal tetapi sematamata hanya anugerah Allah, sehingga hal ini membawa kita semakin menyadari status kita dihadapan Allah yang hanyalah ciptaan dan tidak ada ssattu alasan pun untuk menentang penciptanya. Jadi, semakin mengerti anugerah Allah membawa kita semakin mengasihi Allah dan mentaati-Nya.

\section{Mempersembahkan Tubuh sebagai Persembahan yang Hidup, Kudus, dan Berkenan (ay. 1)}

Dalam bagian ini ada dua kata yang digunakan untuk persembahan yaitu to present (KJV) atau to offer (NIV) yang dalam bahasa Yunani parasth/sai, yang diterjemahkan persembahkanlah. Dan kata yang kedua Sacrifice, dalam bahasa Yunani qusi, an yang diterjemahkan persembahan. Kedua istilah ini memiliki keterkaitan satu dengan yang lain. Rasul Paulus memberi nasehat dan pada bagian ini dan nasehat ini dikonkritkan lagi yaitu dengan mempersembahkan tubuh sebagai persembahan yang hidup, yang kudus dan yang berkenan. Istilah yang digunakan untuk mempersembahkan yaitu parasth/sai dalam bentuk kata kerja, infinitif, aorist aktif, ${ }^{40}$ yaitu menyatakan suatu perbuatan yang dilakukan hanya satu kali saja. Strong menjelaskan kata ini dengan akar kata pari,sthmi dan mengalami perpanjangan menjadi paristano diterjemahkan to stand beside. ${ }^{41}$ A Linguistic Key memberi pengertian untuk istilah ini demikian: parasth/sai aor. Inf. pari, stemi, to present, a technical term to presenting a sacrifice, literally meaning "to be place beside" for any purpose..$^{42}$ Istilah parasth/sai sudah digunakan pada pasal 6:13, 16, 19 dan dalam bagian ini (ps. 6) kata kerja yang digunakan adalah paristanai. Berkenaan dengan hal ini Thomas Van den End menjelaskan demikian:

\footnotetext{
${ }^{39}$ Cranfield, Ibid.

${ }^{40}$ Barbara and Friberg (ed.), Analytical..., 499

${ }^{41}$ Strong, Strong's Dictionary..., 676

${ }^{42}$ Reinecker \& Roger, A Linguistic..., 375
} 
Pemakaian istilah paristanai dalam bagian ini (ps. 6) berkaitan dengan suasana lingkungan istana: menyediakan, mengabdikan kepada raja. Sebaliknya disini (ps. 12), istilah paristanai merupakan istilah peribadatan dari lingkungan bait Allah: mempersembahkan (kurban). Jadi gagasan dasar disini sama dengan yang terdapat dalam pasal 6:12-14 (penyembahan diri kepada Allah secara total), namun penjabarannya berbeda. ${ }^{43}$

Dalam hubungan dengan hal ini juga Cranfield menjelaskan istilah parasth/sai yang digunakan dalam bagian ini adalah istilah teknis dari ritual agama. ${ }^{44} \mathrm{Hal}$ ini diungkapkan juga oleh Loen Morris demikian: "Paul's verb 'offer' could be used of offering of various kinds (it is used, e.g., in 6:13, 16, 19), but it was a techinal term for ofering of sacrifice. Maka kata to offer adalah penjelasan pengantar untuk istilah sw, mata. Yang dipersembahkan adalah tubuh ini menjadi persembahan yang hidup, kudus dan berkenan kepada Allah. Istilah tubuh yang digunakan oleh Paulus disini sw,ma. Istilah ini memiliki beberapa makna karena istilah ini telah mengalami perkembangan yaitu digunakan oleh beberapa filsuf. Yang pertama Plato. Ia menuliskan hal ini demikian:

The body is only the abode of pre-existent soul. Death frees the soul from the body. The picture of the body was also applied to the cosmos. The latter is ruled and directed by divine soul. Zeus conceals everything in himself and lets it all proceed from himself. Similarly may can be represented as a microcosm. ${ }^{45}$

Tetapi ada yang kontras mengenai ide ini seperti yang dijelaskan oleh Aritoteles demikian: "The body is primarily that by which the soul becomes something particular. The bond between body and soul is thus indissoluble."46 Epictetus seorang filsuf juga memberikan pengertian tentang tubuh yaitu membuat gambaran antara jiwa dan daging lebih daripada tubuh. Juga Stoa tentang ide dikotomi dari tubuh dan jiwa serta Marcus Aurelius yang mengatakan tentang tiga bagian manusia demikian: "there are three parts of which thou art composed: body, pneuma (spirit, soul) and Nous (mind, reason)." Dalam literatur Yahudi ditemukan bahwa istilah Sw, ma memiliki hubungan dengan sex. ${ }^{47}$ Akan tetapi penggunaan istilah sw, ma di sini bukan atas dasar pemikiran filsafat Yunani yang

\footnotetext{
${ }^{43}$ Van den End, Tafsiran Alkitab: Surat..., 563-564

${ }^{44}$ Cranfield, Epistle..., 598

${ }^{45}$ Brown (ed.), Dictionary of New Testament..., 232

${ }^{46} \mathrm{Ibid}$.

${ }^{47}$ Ibid.
} 
cenderung merendahkan tubuh sebagai jahat, penjahat dari akal yang baik. Secara spesifik lagi dalam tulisan Paulus, istilah $\mathrm{sw}$, ma yang digunakan adalah menunjuk kepada keseluruhan hidup manusia. Bultman mengatakan tentang istilah $\mathrm{Sw}$, ma dalam Roma 12:1 ini demikian: "Rom 12:1 clearly show that the 'soma' is not merely an outer form but the whole person." 48 Cranfield mengutip komentar Calvin tentang istilah body demikian: "by bodies, he means not only our skin and bones, but totality of which we are composed... in bidding us present our selves...). The Christian is to offer to God himself entire-himself in the whole of his concrete life." 15 Leon Morris menjelaskan istilah body di sini demikian: "The use of the term bodies interesting, for Paul surely expected Christians to offer to God not only their bodies but their whole selver." 16

Dengan demikian penggunaan istilah tubuh menyangkut totalitas hidup manusia, tidak hanyak dibatasi pada satu bagian saja. Ini berarti bahwa seluruh kemampuan dan kegiatan kita harus dipersembahkan kepada Tuhan. Penyerahan atau persembahan hidup kita bukan merupakan sesuatu yang dilakukan sekali saja dalam proses pendewasaan. Tetapi yang dimaksudkan dengan hal ini ialah hidup dalam ketaatan karena iman yang bertumbuh, dimana anggota-anggota tubuh kita harus menjadi alat-alat kebenaran, dan kita hidup dalam pembaharuan hidup. ${ }^{17}$ Tubuh yang dipersembahkan kepada Allah adalah sebagai persembahan. Istilah yang digunakan untuk persembahan di sini adalah Sacrifies (KJV, NIV), qusi, an bentuk dasar dari kata bendanya qusi, a dan didefinisikan oleh Vine:

qusi, a primarly denotes the act of offering; then objectively, that which is offeres (a) of idolatrous sacrifice (Act 7:4); (b) of animal or other sacrifices, as offered under the law (Matt 9:13); 12:7; Mark 9:49; Luke 2:24; Act 7:24; ICor 10:18; Heb 5:1; 7:27). (c) of Christ, in His Sacrifice on the cross (Eph 5:2; Heb 9:23) where the plural antitypically comprehends the various forms of Levitical sacrifices in their typical character. (d) Metaphorically, (1) of the body of the beliver presented to God as a living sacrifice (Rom 12:1); (2) of faith, (Phil 2:17); (3) of material assistance rendered to servant of God (Phil 4:18); (4) of Praise (Heb 13:15); (5) of doing good to others and communicating with their needs, (Heb 13:16). (6) of

\footnotetext{
${ }^{48}$ Brown (ed.), Dictionary of New Testament..., 234

${ }^{15}$ Cranfield, The Epistle..., 598

${ }^{16}$ Morris, The Epistle..., 433

${ }^{17}$ Hegelberg, Tafsiran Roma..., 235
} 
spiritual sacrifices in general, offered by believers as a holy priesthood (1Pet 2:5). ${ }^{18}$

Istilah sacrifies di sini menunjukan suatu tindakan atau aktifitas yang memiliki objek atau materi. Oleh karena ibadah selalu identik dengan kurban. Hal ini sangat jelas dalam PL, bahwa untuk mengadakan pendamaian dengan Allah perlu adanya kurban. Tetapi konsep Paulus disini agak berbeda oleh karena bagi Paulus sendiri, Kristus adalah kurban yang mulia untuk pendamaian dengan Allah dan hal ini adalah sempurna (Ef 5:2). Dan karena Kristus telah menjadi kurban, maka bagi orang yang percaya kepada Kristus dituntut untuk memberikan persembahan yaitu melalui hidup seutuhnya, tanpa menyisihkan sebagian untuk orang lain atau diri sendiri, tetapi totalitas hidup ini dipersembahkan bagi Tuhan, atau dalam pengertian lain bukan pemberian kita yang Tuhan kehendaki tetapi Ia menghendaki kita sendiri. ${ }^{19}$ Dan persembahan yang kita berikan kepada Allah adalah suatu persembahan yang hidup. Istilah hidup yang digunakan dalam bagian ini adalah $\mathrm{zw} / \mathrm{san}$, living (NIV, KJV). Kata ini bersifat sebagai objek dari kata qusi, an dan juga memberikan penjelasan tentang kata qusi, an (sacrifices) itu sendiri, atau living adalah merupakan sifat dari qusi, an dan hal ini terus menerus terjadi. Istilah $\mathrm{zw} / \mathrm{san}$ memiliki akar kata $\mathrm{zw} /$. Kata ini digunakan sebanyak 23 kali secara khusus dalam kitab Roma. Istilah ini juga berhubungan dengan zoe (life). Seperti dalam agama-agama kuno yang lain, istilah zoe, digunakan pada masa kekristenan mula-mula untuk menjelaskan tentang keselamatan. ${ }^{20}$ Dictionary of Paul and His Letter menjelaskan zoe, demikian: "Zoe is used in Paul to mean something other than mere physical existence; it refers to unique quality of life which comes through faith in union with Christ." ${ }^{21}$ Jadi, sesuatu yang hidup tidak hanya hal fisik saja tetapi lebih dari itu adalah spiritual. Douglas Moo menjelaskan istilah living demikian: "living, a theological sense," as those who have been brought to new spiritual life." 22 Hegelberg memberikan penjelasan juga tentang persembahan yang hidup dan melihat sisi PL dan PB tentang Persembahan, demikian:

\footnotetext{
${ }^{18}$ Vine. M.A, Expository Dictionary..., 985

${ }^{19}$ Van den End, Surat Roma..., 564

${ }^{20}$ Balz \& Schneider (ed.), Exegetical Dictionary..., 105

${ }^{21}$ Gerald F. Hawthorne, Ralph P. Martin \& Daniel G. Reid (eds.), Dictionary of Paul and His Letter (Leicester: Inter Varsity Press, 1993), 554

${ }^{22}$ Douglas Moo, The New International Commentary on the New Testament, The Epistle of Romans (Grand Rapids, Michigan: Zondervan, 1996), 751
} 
Dalam ibadah PL tubuh-tubuh binatang yang hidup dimatikan untuk dipersembahkan di mezbah Allah, sedangkan dalam ibadah kita, tubuh-tubuh yang mati dipersembahkan sebagai persembahan yang hidup oleh karena kuasa Roh Allah. Bukankah kontras antara ibadah dalam Hukum Taurat dan ibadah kita dalam kasih karunia Allah mencerminkan tema surat Roma, yaitu bahwa orang yang dibenarkan karena iman akan hidup. Dalam ibadah diluar Kristus, segala macam persembahan yang mati dipersembahankan kepada Allah. Dalam Kristus, tubuh kita yang mati dihidupkanNya, dan itu menjadi persembahan kita. ${ }^{23}$

Oleh karena itu istilah hidup di sini menunjukan suatu kondisi hidup yang baru, yaitu hidup yang dibaharui oleh Roh Kudus (8:11), karena tanpa pembaharuan oleh Roh Kudus, maka hidup kita mati yaitu tetap dalam dosa dan hal ini membawa kita untuk tidak dapat melakukan kehendak Allah, dalam hal ini memberikan persembahan yang hidup. Selain persembahan yang hidup, ada juga kriteria lain yang dicatat oleh Paulus dalam bagian ini yaitu kudus, holy (KJV, NIV) yang digunakan di sini adalah dari kata a ' $\mathrm{g}$ i, an dari kata dasar a [gioj yaitu sacred (physically-pure); morally, blameless or relegious; ceremonially, consecrated: (most) holy (one thing), saint. ${ }^{24}$

Maka istilah kudus disini adalah menunjuk kepada sifat Allah yang kudus dan juga menyangkut perubahan moral dan spiritual orang percaya yang sudah dibenarkan, yang sudah dilahirkan kembali. Dikaruniai hidup baru oleh Tuhan, sebagaimana yang Paulus jelaskan dalam pasal 7-8. Istilah kudus ini juga seringkali Paulus gunakan dalam hubungan dengan pembenaran artinya seseorang dikatakan kudus karena telah mengalami pembenaran oleh Allah. Itu sebabnya istilah kudus disini merupakan bagian yang penting dalam persembahan kepada Allah, karena Dia adalah Allah yang kudus menerima persembahan yang kudus juga dari umat-Nya. Dalam pengertian lain Allah hanya menghendaki persembahan yang kudus dengan demikian persembahan itu adalah menyenangkan hati Tuhan atau berkenan kepada Allah. Antara kekudusan dan menyenangkan hati Allah merupakan satu bagian yang tidak dapat terpisahkan. Murray menjelaskan demikian:

Holiness is contrasted with the defilement which characterizes the body of sin and with all sensual lust. Holiness is the fundamental character and to be well-pleasing to God the governing principle of a believer. These qualities have reference to his body as well as to

\footnotetext{
${ }^{23}$ Hagelberg, Tafsiran Roma..., 235-236

${ }^{24}$ Strong, Strong Dictionary..., 566
} 
his spirit and show hoe ethical character belongs up the body and to its functions. No terms could certify this fact more than "holy and well-pleasing to God". ${ }^{25}$

Sehingga menyenangkan hati Tuhan adalah merupakan sifat dari persembahan yang kudus. Istilah eureston yang digunakan dalam bagian ini memiliki bentuk kata yang sama dengan istilah a ’gi, an -hagian- (holy) yaitu kata sifat, akusatif, feminim tunggal. Hal ini berarti bahwa menyenangkan hati Tuhan menandakan persembahan kurban dan persembahan kurban disini adalah benar dan layak dimana hal ini sesuai dengan keinginan Allah dan Dia menerimanya.

\section{Ibadah yang Sejati (ay. 1)}

Dalam bagian ini ada dua istilah yang akan diteliti yaitu logi kh.n dan latrei, an. Yang pertama adalah kata latrei,an yaitu berasal dari akar kata latrei, a dalam bentuk kata benda, akusatif, feminim, tunggal, ${ }^{26}$ diterjemahkan ibadah. Dalam bahasa Yunani umum istilah latrei, a ini berarti pengabdian. Akan tetapi kata ini mengalami perkembangan dan kemudian diterjemahkan ibadah. Barclay menjelaskan hal ini demikian:

Kata latreia itu adalah kata benda dari kata kerjanya, latreuein. Latreuein berarti, berkerja untuk mendapat upah atau gaji. Kata itu dipakai untuk pekerja-pekerja yang bekerja bagi seseorang dan sebagai ganti tenaga dan usahanya, orang itu membayarnya. Itu merupakan pekerjaan sukarela dan bukannya perbudakan. Kemudian artinya dipakai dengan melayani; dan akhirnya mengandung arti: apa yang kepadanya seseorang mengabdikan seluruh hidupnya... akhirnya kata itu menjadi kata yang khusus mengenai orang yang mengabdikan dirinya kepada dewa-dewa. Di dalam Alkitab kata itu tak pernah berarti pelayanan pada sesama; tetapi selalu dipakai untuk pelayanan kepada Allah dan ibadah kepada Allah. ${ }^{27}$

Istilah latreia juga digunakan dalam LXX dengan kata abad yang diterjemahkan hamba. Kemudian istilah ini digunakan dalam hubungannya dengan keagamaan. Brown menambahkan lagi penggunaan istilah ini pada

${ }^{25}$ John Murray, The Epistle to the Romans (Great Britain: W \& J Makay Limited, Chathan, n.d.), 112

${ }^{26}$ Barbara \& Timothy Friberg (Ed), Analitycal Greek New Testament (Grand Rapids, Michigan: Zondervan, 1982), 499

${ }^{27}$ Barclay, Pemahaman Alkitab..., 233-234 
LXX memiliki hubungan dengan istilah leiturgeo demikian: In $L X X$, Latreueo is very close to-Leitourgeo in meaning, but the latter is used exclusively for the service of the priest, while the former means the service of God by the whole people and by the individual, both outwardly in the cultus and inwardly the heart. ${ }^{28}$ Rasul Paulus mengambil istilah ini dari PL, yang sangat berhubungan dengan kaum Yahudi. Akan tetapi penggunaan istilah Latreian di sini, dimaksudkan oleh Paulus untuk membedakan antara ibadah orang Yahudi dengan ibadah orang Kristen. Berkanaan dengan hal ini Douglas Moo menjelaskan demikian:

Paul probably chooses the term deliberately to create a contrast between Jewish and Christian form of worship. For Christians, there is no more "cult" or "sacrifice" in any literal sense. While the Jew looked to the Jerusalem temple and it's cult as the center of worship, the Christian looks back to the once-for-all sacrifice of Christ. Christians are all priests (1Pet 2:5; Rev 1:6; 5:10; 20:6), forming together the temple where God now reveals himself in a special way. ${ }^{29}$

Jelas bahwa ibadah yang dimaksudkan Paulus bukanlah hanya sekedar suatu upacara tertentu, pada tempat tertentu, pada waktu tertentu dan aksi tertentu tetapi ibadah berlaku dimana saja, dalam aktifitas apa saja karena ibadah itu adalah persembahan hidup ini, setiap saat kepada Allah dan ibadah yang kita lakukan kepada Allah adalah ibadah yang sejati atau masuk akal. Dan inilah istilah kedua yang digunakan untuk masuk akal yaitu logikh.n dalam bentuk kata sifat, akusatif, feminim, tunggal yang diterjemahkan oleh KJV reasonable. Istilah logikh.n dari akar kata logikos adalah istilah yang digunakan dalam filsafat Yunani. Berkenaan dengan hal ini Van den End menjelaskan secara etimologis istilah logikos demikian:

Dalam bahasa Yunani, logikos merupakan istilah filsafat. Artinya secara harfiah 'sesuai akal budi.' Tetapi khususnya dalam aliran Stoa, logikos berarti: apa yang sesuai dengan kodrat alam semesta itu, yaitu sang logos yang menjiwai dan mengatur alam semesta itu. Logos ilahi itu hadir pula dalam diri manusia. Maka, jika manusia membiarkan logos itu mengendalikan kehidupan dirinya, ia hidup secara logikos, yaitu sesuai dengan logos yang menguasai alam semesta. Dalam mistik Helenistik, logikos mendapat arti 'batiniah,' 'sesuai dengan kodrat rohani manusia', sehingga menjadi lawan

\footnotetext{
${ }^{28}$ Brown (ed.), Dictionary of New Testament..., 550

${ }^{29}$ Moo, The Epistle..., 753-754
} 
'lahiriah' (yang lahiriah adalah persembahan kurban, upacaraupacara, dsb). Dalam lingkungan mistik itu terdapat istilah logike thusia, 'persembahan budiman.' Pengarang Yahudi Philo menerima arti itu dan mempertentangkan sikap yang logikos dengan sikap hanya mementingkan penyembahan lahiriah. ${ }^{30}$

Istilah logikos ini tidak terdapat dalam PL, maka jelas bahwa Paulus menggunakan istilah filsafat Yunani ini tetapi memberikan pengertian yang lain. Berhubungan dengan hal ini Cranfield menjelaskan demikian:

We must beware, however, of understanding 'rational' as though Paul were a Stoic philosopher. For Paul the true worship is rational not in the sense of being consistent with the natural rationality of man but in the sense of being consistent with a proper understanding of the truth of God revealed in Jesus Christ. ${ }^{31}$

Jadi, istilah logikh.n di sini memiliki makna spiritual bukan dalam makna filosofis lagi, seperti yang dijelaskan John Stott demikian: Paul is clear that the presentation of our bodies is our spiritual act of worship. It is a significant Christian paradox. No worship is pleasing to God which is purely inward, abstract and mystical; it must express itself in concrete acts of service performed by our bodies. ${ }^{32}$ Oleh karena itu ibadah yang kita lakukan adalah merupakan tindakan spiritual yang masuk akal dimana adanya keterikatan antara ketiga hal ini yaitu hati, pikiran dan perbuatan, ketiga hal ini dalam tuntunan Roh Kudus serta sesuai dengan Firman Allah.

\section{PENUTUP: IMPLIKASI}

Dalam bagian ini penulis akan membahas ibadah menurut Roma 12:1-2 dan implikasinya bagi ibadah masa kini, yang meliputi: implikasi teologis, etis, soteriologis, eklesiologis, dan eskatologis.

\section{Implikasi Teologis}

Ibadah yang sejati bukan hanya didasarkan pada pengalaman tetapi didasarkan pada sebuah pemahaman teologis yang mendasar. Artinya

\footnotetext{
${ }^{30}$ Van den End, Surat Roma..., 566

${ }^{31}$ Cranfield, The Epistle..., 604-605

${ }^{32}$ Stott, The Message of Romans...,
} 
ibadah harus di dasarkan pada Alkitab yang adalah Firman Allah. Maka kebenaran dari ibadah bersifat mutlak dan harus dilakukan. Jika ibadah di dasarkan kepada pengalaman pribadi, maka kebenaran dari ibadah tersebut tergantung apa kata pribadi sehingga nilai kebenarannya adalah relativ, manusia sebagai penentu kebenaran. Jika kebenaran ibadah adalah relativ, maka ibadah dapat di tolak yang berarti perlawanan terhadap Allah.

Ibadah yang didasarkan pada pengalaman semakin jelas tujuannya yaitu ibadah antropocentris. Karena itu, ibadah harus dikaji secara teologis dengan melihat beberapa aspek penting yang saling berkaitan satu dengan yang lain dan berfondasi pada Alkitab. Jika hal ini dilakukan, maka dipastikan bahwa ibadah tersebut adalah ibadah yang sehat karena memberi gizi yang tepat bagi orang-orang yang melaksanakan ibadah.

\section{Implikasi Etis}

Ibadah adalah sebuah penyembahan yang dilakukan oleh para penyembah. Karenanya ibadah memberi pengaruh kepada penyembah. Jika seseorang beribadah tetapi tidak menunjukkan perubahan karakter dalam hidupnya maka dia tidak memahami dan melakukan ibadah yang sebenarnya. Karena ibadah yang sejati selalu mengubah hati penyembah. Ini berarti bahwa ibadah memberi impact dalam perilaku setiap orang yang melakukan ibadah. Problematika hidup yang seringkali terjadi dalam kehidupan jemaat Kristen bukan hanya karena di dasarkan pada istilah "karena kita ini manusia lemah," tetapi karena pemahaman ibadah yang hanya dibatasi oleh ritus, sistem ceremonial ataupun tempat tertentu. Ibadah yang sejati adalah sebuah gaya hidup. Maka semua aktifitas, kreatifitas dan hal apa saja yang dilakukan adalah ibadah, sehingga semua orang yang memiliki konsep ini akan semakin bijaksana hidup dan memiliki makna hidup yang tinggi, yaitu hidup adalah memuliakan Allah sampai selamanya.

\section{Implikasi Soteriologis}

Hakekat dari Ibadah yang sejati adalah inisiatif Allah semata. Ini berarti bahwa jika seseorang mampu melakukan ibadah itu bukan karena kekuatan atau inisiatif orang tersebut tetapi pekerjaan Allah. mengapa Allah melakukan hal ini ? Karena Dia adalah Allah yang senang untuk berjumpa dengan umat-Nya. Dan wadah yang diciptakan oleh Allah ibadah. Tetapi perjumpaan dengan Allah melalui ibadah harus melalui syarat Allah. Hal ini dilakukan oleh karena manusia telah jatuh dalam dosa. Syarat mutlak 
dari ibadah yang sejati adalah Justification by faith. Karena tanpa pembenaran oleh Allah tidak ada seorang pun yang mampu menghampiri tahta Allah yang kudus. Karena itu ibadah Kristen adalah ibadah anugerah yaitu refleksi dari keselamatan yang telah Allah kerjakan bukan sebagai sarana untuk mencari keselamatan.

\section{Implikasi Eklesiologi}

Ibadah selalu identik dengan Gereja karena tidak ada Gereja yang tidak beribadah. Selama Gereja ada berarti selama itu pula akan terus ada ibadah, bukan berarti bahwa ibadah tidak bisa dilakukan tanpa Gereja.

Konsep ibadah sangat berpengaruh dalam maju mundurnya sebuah Gereja. Jika Gereja salah bahkan tidak memahami konsep ibadah yang sejati yaitu persembahan totalis hidup manusia kepada Allah yang di dasarkan pada pembenaran oleh Allah, maka Gereja hanya akan menjadi sebuah pusat pesta dimana setiap orang yang datang bebas menumpahkan isi hatinya tanpa melihat aturan-aturan yang ada. Ibadah hanya sebuah alat pemuasaan kebutuhan emosional, sehingga tidak heran bahwa ibadah hanya boleh dilakukan di Gereja saja. Maka ibadah menjadi suatu legalisme dan rutinitas belaka. Ibadah hanya di batasi pada tata cara dan sistem ceremonial yang dilakukan pada waktu tertentu dan tempat tertentu. Bukankah ini sebuah pereduksian ibadah?

Gereja harus mengimplementasikan ibadah sebagai gaya hidup bagi semua jemaat yang datang beribadah sehingga memberi dampak bagi kehidupan sendiri, orang lain dan memuliakan Allah. Serta memberi diri kepada Allah sebagai persembahan yang hidup dan menjalani proses renewing mind sampai Tuhan datang kedua kali.

\section{Implikasi Eskatologis}

Ibadah yang dilakukan adalah sebuah gambaran tentang kehidupan yang akan datang. Karena ibadah memiliki nilai eskatologis. Ketika Yesus menyelamatkan kita itu berarti bahwa kerajaan-Nya telah hadir dalam hidup kita dan kita telah berada dalam kerajaan-Nya. Maka tujuan tertinggi orang beribadah bukan untuk masuk surga tetapi memuliakan Allah. Sehingga ibadah mengadung kepastian. Karena sebuah kepastian maka ada banyak janji yang didengar dan diberikan untuk kekekalan dan itu diterima oleh banyak orang percaya dan di atas semua ini ada pengharapan yang sejati dalam Yesus Kristus. Karena itu ibadah yang dilakukan adalah sebuah 
refleksi jiwa tentang adanya kepastian hidup di masa yang akan bukan hanya sebuah propaganda tanpa kepastian. 